\title{
Morphoagronomic characterization of sorghum cultivar 'CIAP 132R-05' obtained by somatic embryogenesis in the conversion phase using different substrates
}

\author{
Silvio de J. Martínez Medina1,2, Raúl Barbón Rodríguez², Rafael Gómez-Kosky², Novisel Veitía Rodríguez², \\ María Esther González Vega ${ }^{3}$, Orlando Saucedo Castillo', Eduardo Fidel Héctor Ardisana ${ }^{4}$, \\ Sandra Pérez Álvarez ${ }^{5 *}$
}

${ }^{1}$ Centro de Investigaciones Agropecuarias, Universidad Central "Marta Abreu" de Las Villas. Carretera a Camajuaní km 5.5, Santa Clara, Cuba. CP 54830, 'Instituto de Biotecnología de las Plantas, Universidad Central de Las Villas "Marta Abreu". Carretera a Camajuaní km 5.5, Santa Clara, Cuba. CP 54830, ${ }^{3}$ Instituto Nacional de Investigaciones Agrícolas. Carretera a Tapaste km 3,5; San José de las Lajas, Mayabeque, ${ }^{4}$ Instituto de Posgrado, Universidad Técnica de Manabí, Portoviejo, Ecuador, C.P. EC130105, ${ }^{5}$ Facultad de Ciencias Agrícolas y Forestales, Universidad Autónoma de Chihuahua, km 2.5, Carretera Delicias-Rosales, Campus Delicias, CD. Delicias, Chihuahua CP 33000

\section{A B S T R A C T}

Sorghum [Sorghum bicolor (L.) Moench] is an important crop after wheat, corn, rice and barley. The aim of this research was to study morphological characterization of the plant population of grain sorghum cultivar CIAP 132R-05 regenerated via somatic embryogenesis under semi controlled conditions in green house. Plants regenerated from somatic embryos were compared to plants grown from botanical seeds. Both populations of plants were characterized morphologically, taking in account quantitative traits (plant height (cm), stem diameter, number of active leaves per plant, limb length and width, number of active roots per plant, length of the roots (cm), fresh weight (gMF), foliar area $\left(\mathrm{dm}^{2}\right)$, number of shoots per plant) and qualitative traits (albino or variegated plants, color of the leaves). Quantitative characteristics of both populations corresponded with those listed in the National Register of Commercial Varieties of Cuba. However; the population of plants derived from somatic embryos showed significantly higher values for plant height, stem diameter, limb length and width, which may be associated with the physiological rejuvenation produced by the effect of in vitro culture. This allowed to determine the phenotypic stability of the regenerated plants via somatic embryogenesis, by assessing morphological characters in field conditions. The results can be applied to the in vitro propagation of elite plants selected as a product of conventional breeding programs and obtained through the use of different biotechnological methods.

Keywords: Morphological characters; Somaclonal variation; Somatic embryogenesis

\section{INTRODUCTION}

Sorghum is a crop adapted to tropical and subtropical areas of the world. It is a cereal used for human food and animal feed consumption, forages, fibers, as well as in the alcohol and liquor industry for the production of alcoholic beverages (Ignacimuthu and Premkuumar, 2014). Compare with other cereals, this crop is adapted to a wide range of environments and produces grains under unfavorable conditions. Sorghum is widespread, ranks fifth among the most cultivated cereals, after wheat (Triticum aestivum L.), corn (Zea mays L.), rice (Oryza sativa L.) and barley (Hordeum vulgare L.) (Al-Saied, et al., 2014).

Sorghum world production in 2016 was about 65.24 million tons, which represented an increase of 5.42 million tons
(9.06\%) with respect to 2015 (FAO, 2016). In Cuba, the production of sorghum constitutes an alternative for human food and animal feed. In 2015, the country planted 14036 ha, of which 1267.50 ha were from the cultivar 'CIAP 132R-05' with a production of 2535 t representing $24.49 \%$ of the total production (IIG, 2016). This cultivar is very accepted by the producers given its semi-precocious cycle that allows the rotation with the cultivation of the tobacco (Nicotiana tabacum L.), by its average capacity of regrowth, easy manual harvest (low size), high yield under dry conditions $\left(2.5 \mathrm{tha}^{-1}\right)$ and tolerance to biotic stress such as birds and pests (MINAG, 2005). However; sorghum production in Cuba is still limited by pests and birds attack. In addition, from the nutritional point of view it is necessary to improve the composition of essential amino

\footnotetext{
*Corresponding author:

Sandra Pérez Âlvarez, Facultad de Ciencias Agrícolas y Forestales, Universidad Autónoma de Chihuahua, Km 2.5, Carretera DeliciasRosales, Campus Delicias, CD. Delicias, Chihuahua CP 33000. E-mail: perezalvarezsandra2015@gmail.com
} 
acids and to achieve an increase in protein content (Gurel et al., 2009), which could be accomplished through genetic improvement programs.

It should be noted that traditional methods of genetic improvement have not achieved satisfactory results for these characters (essential amino acids and protein content). Therefore, the genetic transformation using biotechnological method may be applied for the genetic improvement of this species, which allows the insertion in the plants of foreign genes that confer the desired characteristics. But for its application, it is an essential requirement to have an efficient methodology for plant regeneration. Somatic embryogenesis is a way to achieve such ends, with good results in this crop (Assem et al., 2014; Hassan et al., 2014).

The conversion phase of somatic embryogenesis is refers to the survival and development of plants produced in vitro from somatic embryos with a pair of leaves in ex vitro environmental conditions, thus arriving to a stage of autotrophic development (Shihe et al., 2006). These plantlets have a poorly developed cuticle, with thin, soft and photosynthetically inactive leaves. These characteristics mean that when they are transferred to the soil, an extra cuticular transpiration occurs, since the humidity of the air in in vivo conditions is lower. On the other hand, their stomata are not sufficiently operative, when they are transplanted to the soil they remain open and an important hydric stress originates in the first hours of conversion (Hazarika, 2003). Given this situation, the plantlets show rapid wilting when transferred to greenhouse conditions; all these problems imply that during the conversion in semi-controlled conditions; the plants derived from somatic embryos suffer affectations in the percentages of survival.

The adaptation of vitroplants to environmental physiological conditions (hardening) is one of the most critical points in the process of obtaining plants through tissue culture. Thus, the bottleneck of the material production is the ex vitro stage. In cassava culture for the adaptation phase, three types of organic substrates were evaluated: MB 1 (solid humus + dry rice husk 1: 1), MB2 (solid humus + chip 1: 1) and $\mathrm{MB}$ (Bocashi) for plant hardening with 8 weeks in vitro. The MB1 substrate allowed the survival and adaptation of $80 \%$ of vitroplants, compared to MB2 32.5\% and MB without any (Macgayver et al., 2015). The effect of substrates elaborated with a mixture of natural zeolite and vermicompost on conversion phase of Coffea arabica L. cv. 'Caturra rojo' plants obtained by somatic embryogenesis was determine, so four treatments were used $(85 \%$ vermicompost $-15 \%$ zeolite, $75 \%$ vermicompost $-25 \%$ zeolite, $65 \%$ vermicompost $-35 \%$ zeolite, $50 \%$ vermicompost $-50 \%$ zeolite), as a result the mixtures with higher content of vermicompost allowed better results in all the variables evaluated (Barbon et al., 2014).

Given the problems described above and considering the importance of sorghum cultivation in Cuba, the aim of this research was to study characterize morphoagronomical characters of the graniferous sorghum plants [Sorghum bicolor (L.) Moench] cultivar 'CIAP 132R-05' obtained by somatic embryogenesis in the conversion phase.

\section{MATERIALS AND METHODS}

The research was carried out at the Institute of Plant Biotechnology (IBP) at the Central University "Marta Abreu" of Las Villas (UCLV), Santa Clara (Cuba), during the period between July and August 2015. The experiments were done in a greenhouse under semi-controlled conditions.

\section{Plant material}

The in vitro germinated somatic embryos of sorghum (S. bicolor) cultivar 'CIAP 132R-05' were used in this study. As initial material for somatic embryos, basic seed from the germplasm bank of the Agronomic Research Center (CIAP) was used. During the experiments, a population of plants from botanical commercial seeds was used to compare with plants from botanical basic seeds.

\section{Conversion phase: Effect of different substrates}

Different substrates (earthworm humus, zeolite and their mixtures) were used to evaluate their effect in the conversion of the in vitro plants obtained from the germinated somatic embryos of the sorghum cultivar 'CIAP 132R-05'. The earthworm was prepared using the California red worm (Eisenia foetida) and compost was prepared as the worm food. Once ready, the compost is placed in beds that can be $1 \mathrm{~m}$ wide, $2 \mathrm{~m}$ long and $0.15 \mathrm{~m}$ deep, where the worms were planted at a rate of: $1 \mathrm{~kg}$ per bed and the process of humus elaboration by of the worms took 120 days. During this period, adequate humidity must be maintained and the bed must be shaded. In order to harvest the humus, traps were placed, with the purpose of extracting as many earthworms from the beds. The traps are piles of fresh food that is placed in the center of the beds, which is where the worms are going to be placed. This process was repeated 3 times in a week. Once the worms were gone, the material is ready to be used as an organic fertilizer on farmland. It is a product of coffee-gray color, granulated and odorless.

The treatments established were:

$\mathrm{T} 1=100 \%$ earthworm humus; $\mathrm{T} 2=80 \%$ earthworm humus $+20 \%$ Zeolite; T3 $=50 \%$ earthworm humus $+50 \%$ 
Zeolite; T4 $=100 \%$ Zeolite. All the zeolite had a granule size $<4$. To evaluate the effect of the treatments under study, the in vitro plants obtained from somatic embryos were transferred to conversion conditions in a greenhouse. The transferred plants had the following characteristics: length between 30 and $50 \mathrm{~mm}$, three leaves and two to three roots. The plants were planted in polyurethane containers of 150 alveoli $\left(120 \mathrm{~cm}^{3}\right.$ each).

Fertilization was performed according to Salvador et al. (2007) two times; it was applied in the substrate $1 / 3$ of the complete formula 140-60-60 (N-P-K) at the beginning of the conversion phase and the rest after 25 days of culture. In addition, the growth regulator Fitomas-E (ICIDCA, Cuba) was applied at a rate of $3 \mathrm{~L} \cdot \mathrm{ha}^{-1}$ after 30 and 60 days of culture.

Irrigation was performed by micro-sprinkling, with low pressure sprinklers $\left(2.0 \mathrm{~kg} \mathrm{~cm}{ }^{2}\right.$ and a flow rate of $\left.1221 . \mathrm{h}^{-1}\right)$. During the first days of cultivation in this phase four daily interval irrigations were carried out (8:00 am, 10:00 am, 12:00 pm and 4:00 pm) each for one minute. After the fifth day, three daily interval irrigations (8:00 a.m., 12:00 m and 4:00 p.m.) and a duration of two minutes each were applied. With this frequency a relative humidity in the interior of the greenhouse of $85-90 \%$ was guaranteed.

For each treatment, three replications of 50 in vitro plants each one were made. After 15 days and up to 30 days the following variables i.e; survival $(\%)$, plant height $(\mathrm{cm})$, number of active leaves per plant, number of active roots per plant, length of roots $(\mathrm{cm})$.were evaluated with a periodicity of five days.

For each treatment, three replications of 450 in vitro plants each were used. After 15 days and up to 30 days the following variables i.e; survival (\%), plant height $(\mathrm{cm})$, number of active leaves per plant, number of active roots per plant, length of roots $(\mathrm{cm})$. were evaluated with a periodicity of five days, and eighteen sampling dates (25 plants each) were carried out.

\section{Morphological and physiological characterization of plants obtained from somatic embryos}

The morphological and physiological characterization of plants obtained from somatic embryos was done according to the National Register of Commercial Varieties (MINAG, 2005) for the cultivar under study.

The plants obtained from somatic embryos were compared with plants from botanical seed that were cultivated for 30 days in the same substrate and similar semicontrolled conditions in a greenhouse. The botanical seeds with the basic category were previously pre-germinated until they reached a height of $5 \mathrm{~cm}$, three leaves and a fibrous root system with one main root and five or more secondary roots. For each treatment 150 plants were used that were planted in the same conditions as the plants obtained from somatic embryos.

For each treatment 450 plants were used and 50 plants were evaluated per treatment. At 15, 20, 25 and 30 days after the transplant to semi-controlled conditions, the following variables i.e plant height $(\mathrm{cm})$, number of active leaves per plant, number of active roots per plant, length of the roots $(\mathrm{cm})$, fresh mass $(\mathrm{gMF})$, foliar area $\left(\mathrm{dm}^{2}\right)$, number of shoot per plant were evaluated.

\section{Statistical analysis}

A completely randomized experimental design was carried out during the conversion phase of somatic embryos study. The experiments were repeated twice. To check the normality of the variables, the Shapiro-Wilk (1965) test was used. The Kruskal and Wallis H (1952) test and the nonparametric Mann-Whitney U (Cited by Dineen and Blakesley, 1973) test were used for comparison between pairs of groups. In all cases, the differences were established for $\mathrm{p} \leq 0.05$. For the statistical analysis, the SPSS software package for Windows version 21.0 (IBM Corp. 2013) was used.

\section{RESULTS}

\section{Conversion phase: Effect of different substrates}

Plants with more than three leaves, three roots and between 3 and $5 \mathrm{~cm}$ in height from somatic embryos were used after having gone through the different stages of tissue differentiation (Fig. 1).

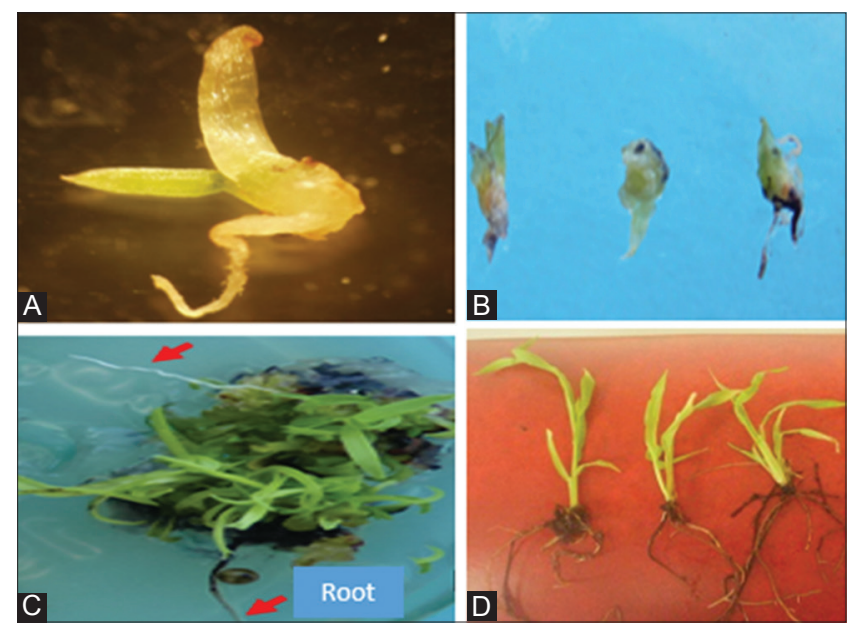

Fig 1. Plants to be transferred to conversion conditions in greenhouse obtained from somatic embryos after going through the different stages of tissue differentiation (A) Somatic embryo in advanced coleoptilar stage (B) Somatic embryos germinated at 7 days of culture, (C) Somatic embryos at 21 days of culture, (r) Roots. (D) Plants obtained from somatic embryos to be transferred to the conversion phase. 
The highest percentage of survival $(100 \%)$ was reached with a substrate composed of $80 \%$ earthworm humus and $20 \%$ zeolite (T2), with significant differences with the rest of the treatments. The lowest percentages of survival were obtained when the substrates of $100 \%$ zeolite (T4) and $50 \%$ earthworm humus $+50 \%$ zeolite (T3) were used (Fig. 2).

Sorghum plants from somatic embryos reached a height of $15 \mathrm{~cm}$ in the substrate composed of $80 \%$ earthworm humus and $20 \%$ zeolite with significant differences with the rest of the treatments, at 30 days under green house conditions. The plants presented a homogeneous growth, with a green coloration (Table 1). Fig. 3).

The superior results achieved with the use of $80 \%$ earthworm humus $+20 \%$ zeolite (T2) are related to the

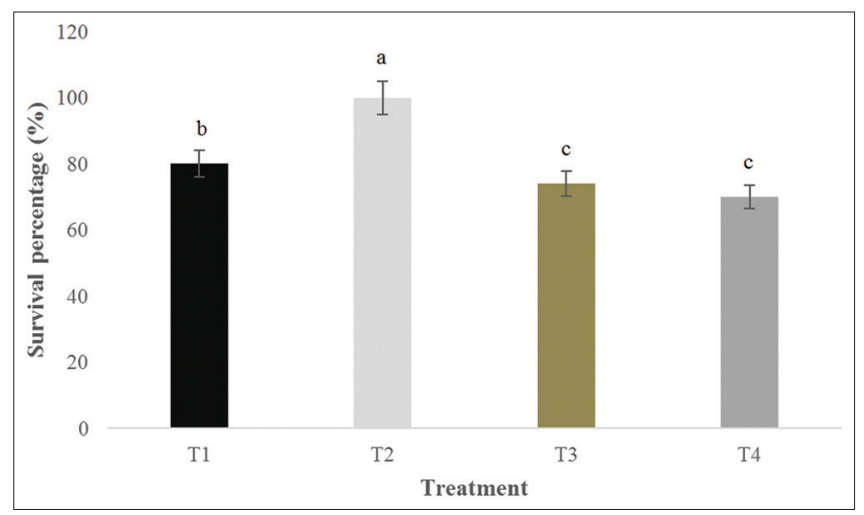

Fig 2. Effect of different substrate on the ex vitro survival (\%) of plants of S. bicolor cultivar 'CIAP 132R-05' obtained via somatic embryogenesis after 30 days in the conversion phase. Different letters on the bars differ according to the Kruskal-Wallis/U test of Mann-Whitney for $p \leq 0.05(n=18)$.

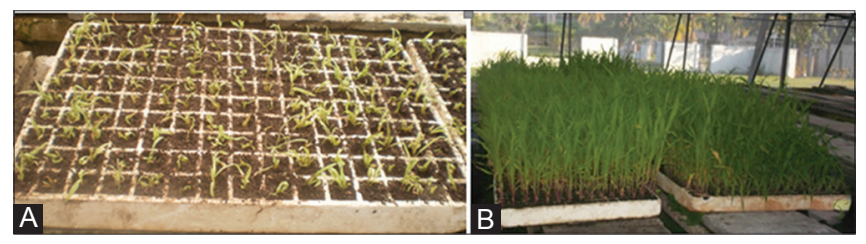

Fig 3. Conversion of somatic embryos of $S$. bicolor cultivar 'CIAP 132R-05' in a substrate composed of: $80 \%$ earthworm humus and $20 \%$ zeolite in the greenhouse. (A) Plants from somatic embryos 3 days after planting, (B) Plants from somatic embryos 30 days after planting in the conversion phase. characteristics that the zeolite gives to the substrate, by stimulating the retention and release of water, as well as exchanging ions. This shows that the amount of organic matter influences to achieve an adequate structure of the substrate and allows an adequate porosity for plant respiration, drainage and water retention.

However, with $50 \%$ earthworm humus $+50 \%$ zeolite substrate (T3) containing the same components, but in a smaller proportion, significantly lower values were reached in the variables evaluated, which could be due to the decrease in the amounts of organic matter and zeolite, thus increasing the porosity, affecting the water retention capacity, as well as a decrease in the nitrogen source for the growth and development of ex vitro plants.

\section{Morphological and physiological characterization of plants obtained from somatic embryos vs plants from botanical seed}

Characterization of plants obtained from somatic embryos was compared to plants from botanical seed to verify the correspondence in the morphological and physiological characters between both populations.

Differences were found in morphological characters between plants from somatic embryos and plants from botanical seed (Fig. 3). At 15 days in semi-controlled conditions of the greenhouse, all the variables, except the number of leaves and shoot per plant were significantly higher in the population of plants from botanical seed. After 20 days, the variables number and length of the roots were significantly higher in plants obtained from somatic embryos; whereas, the variables height, number of leaves, foliar area, fresh and dry mass were significantly higher in plants from botanical seed.

From 25 to 30 days the variables height of the seedlings, number of leaves, leaf area, fresh mass and dry mass were higher in botanical seed plants (Fig. 4 A, B, F, G, H). The variables previously analyzed allowed to differentiate the two populations of plants during the 30 days under semi-controlled conditions in a greenhouse. In this period the variables number and length of the roots were significantly higher in plants obtained from somatic embryos (Fig. 4 C and D). Also, the variable number of

Table 1: Effect of different substrates on the conversion of the plants obtained from somatic embryos of S. bicolor cultivar 'CIAP 132R-05' after 30 days of culture

\begin{tabular}{|c|c|c|c|c|c|c|c|c|}
\hline \multirow[t]{2}{*}{ Substrates } & \multicolumn{2}{|c|}{ Plant height (cm) } & \multicolumn{2}{|c|}{ Leaves number } & \multicolumn{2}{|c|}{ Roots number } & \multicolumn{2}{|c|}{ Roots length (cm) } \\
\hline & Means & Middle ranges & Means & Middle ranges & Means & Middle ranges & Means & Middle ranges \\
\hline $\mathrm{T} 1$ & 12,8 & $164,2 \mathrm{~b}$ & 5,80 & $98,75^{b}$ & 7,40 & $41,98^{b}$ & 7,20 & $41,68^{b}$ \\
\hline T2 & 15,0 & $167,3 \mathrm{a}$ & 6,41 & $125,7^{\text {a }}$ & 11,03 & $92,27^{\text {a }}$ & 12,65 & $45,11^{a}$ \\
\hline T3 & 12,1 & $163,9 \mathrm{~b}$ & 5,75 & $98,15^{b}$ & 5,90 & $19,02^{\circ}$ & 6,01 & $19,56^{c}$ \\
\hline $\mathrm{T} 4$ & 11,8 & $155,5 b$ & 4,05 & $86,55^{c}$ & 5,90 & $14,25^{d}$ & 4,51 & $1,67^{d}$ \\
\hline
\end{tabular}

Mean ranges with different letters within the same column differ according to the Kruskal-Wallis/U test of Mann-Whitney for $p \leq 0.05$ ( $n=18)$. 


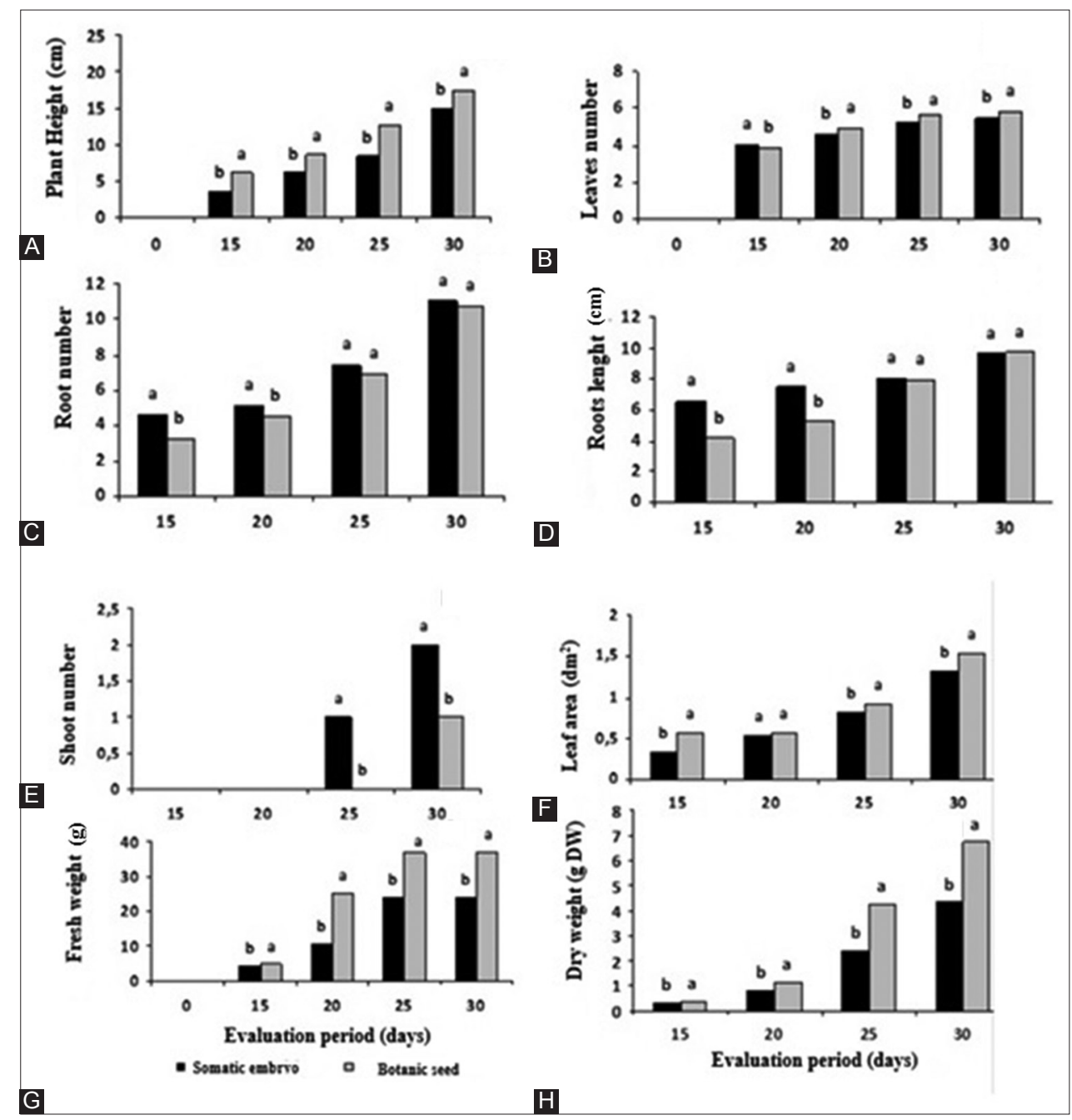

Fig 4. Morphological characters of the plants of $S$. bicolor cultivar 'CIAP 132R-05' obtained from somatic embryos in ex vitro conditions in a substrate with earthworm humus $80 \%$ and zeolite in $20 \%$ (T2) compared to plants obtained from botanical seed. (A) length of stem, (B) number of leaves, $(C)$ number of roots, $(D)$ length of roots, $(E)$ number of shoot, $(F)$ leaf area $(G)$ fresh mass of the plant and $(H)$ dry mass of the plant. Means with different letters on the bars for the same time differ according to the Kruskal-Wallis/U test of Mann-Whitney for $p \leq 0.05$ ( $n=18$ ).

shoot after 25 days under semi-controlled conditions in the greenhouse was higher in the plants from somatic embryos (Fig. 4 E).

There was correspondence in the qualitative phenotypic characters evaluated related to the leaves (Porte of the limbus, color of the main vein of the limbus, color of the limbus), the stems (Pigmentation of the knots, juiciness) and the panicle (Panicle density, type panicle, panicle shape, panicle dehiscence, color of the glume, fluffiness of the glume, shape of the glume, shape of the apex of the spikelet, color of the stigmas, edge of the glume, coloring of the anthers, color of the grain, shape of the grain, color of the plant in the harvest and earliness) between both populations of plants during the conversion phase. These qualitative characteristics correspond to the description referred to in the national registry of commercial varieties (MINAG, 2005) for the cultivar CIAP 132R-05.

\section{DISCUSSION}

\section{Conversion phase: Effect of different substrates}

In Cuba the production of sorghum is limited by a group of factors such as: birds attack, diseases, pests and high content of tannins that affects the quality and quantity of protein in the grain, as well as its composition in amino acids; for all these reasons, it is necessary to develop genetic improvement programs (Pérez et al., 2010).

At present genetic transformation is a powerful method for genetic improvement, for which an efficient plant regeneration protocol is needed. Embryogenesis is a pathway for plant regeneration in this crop (Zhong et al., 1998). This regeneration path is a simple, fast method to produce a large number of seedlings (Baskaran et al., 2005).

Sorghum plants obtained from somatic embryos were used after having gone through the different stages of 
tissue differentiation. The best results for the substrates used in the conversion phase were achieved with a mix of $80 \%$ earthworm humus and $20 \%$ zeolite (T2), with significant differences with the rest of the treatments. This result could be due to the fact that this substrate guarantees permeability, a high water retention ability, low density, cation exchange capacity, possibility to keep the $\mathrm{pH}$ constant and minimum speed of decomposition. These are characteristics of a good substrate that stimulate the development of plants and provide good support (Henny et al. (2004).

The use of the substrate T2 showed good results also for the height of the plant, the number of leaves and the number and length of the roots.

The quality of the substrate during the ex vitro phase defines the chance for the plant to express its productive potential in favorable climatic conditions. Zeolite is an active mineral of inorganic origin, which improves the physical and chemical characteristics of the substrate (Sangeetha and Baskar, 2016).

The high survival achieved in the present work with the use of earthworm humus in combination with zeolite (80:20) was higher than the obtained by other authors for this crop, but using other mixtures of components in the substrate. In this regard, Pola and Sarada (2006) achieved a 60\% survival rate during the ex vitro phase of the genotypes 'IS 3566 ', SPV 475 ', CSV 13 ',' CSV 15 ',' CSV 112 'and 'IS 348' on a substrate with a 1:1 ratio of soil and vermiculite.

Other authors such as Baskaran et al. (2005) using sorghum cultivars 'NSH27' and ' $\mathrm{K} 8$ ', achieved a 100\% survival during the first three weeks in a substrate consisting of soil, organic matter and sand (2:1:1). Concerning the above mentioned, Díaz et al. (2004) pointed out that the efficiency of the process of adapting the in vitro obtained plants to ex vitro conditions depends to a large extent on the choice of the substrate and on achieving an adequate relationship between the components of the mixture to ensure a good survival of the plantlets. The percentages of survival achieved in the present work (100\%) are higher than those reported by Amali et al. (2014) for the sorghum cultivar M35-1 (70\%). In agreement with the results reported by these authors and Polumahanthi et al. (2014) plants obtained from somatic embryos were phenotypically similar to botanical seed.

In other species of monocotyledonous plant the results of the acclimatization in different substrates do not correspond with those of the present work. Hurtado et al. (2012) found in Bambusa vulgaris Schrad. Ex. J. C. Wendl that the type of substrate influenced the acclimatization of the in vitro obtained plants in the greenhouse, whilst for survival percentages, they achieved the best results for plant height using a substrate composed of earthworm humus mixture (50\%) and Zeolite (50\%), similar to T3 treatment used in this study.

The leaves emitted by the plants under in vitro conditions constitute a reservoir of carbohydrates, which are used in the growth and development of the plantlets. When these plantlets are transferred to ex vitro conditions, they maintain this function until a new foliar emission occurs, according to Hazarika (2003).

However, Davies (2010) reported that the formation of a developed root system will allow the absorption of soil and water nutrients for the survival and growth of plants in these new growing conditions. The roots of the plantlets grown under in vitro conditions present a different pattern when planted in an ex vitro substrate. The composition of the substrate influences the survival, growth and development of the plants obtained from somatic embryos during their conversion. The plants derived from somatic embryos, when planted in the substrate composed of $80 \%$ earthworm humus $+20 \%$ zeolite (T2) showed the highest survival values, as well as plant height, number of leaves, number and length of the roots; as a consequence, this substrate was selected for the conversion phase of plants obtained from somatic embryos.

\section{Morphological and physiological characterization of plants obtained from somatic embryos}

The plants regenerated from somatic sorghum embryos were able to adapt themselves to grow under the semicontrolled conditions of the greenhouse. Significant differences were distinguished in favor of plants from botanical seed in their structure and growth in terms of stem length, number of leaves, foliar area, fresh and dry mass. This result could be due to the fact that the plants obtained from somatic embryos have been continuously exposed to a culture environment that provided a minimum of stress and adequate conditions for their development, which turn them into mixotrophic individuals; thus, when passing to the conversion phase they have to adapt to autotrophic nutrition and environmental conditions that initially create stress in them (Hazarika, 2003).

As reported by González (2014), plants grown in vitro have a poorly developed cuticle, with thin, soft leaves and reduced photosynthetic activity, and when they are transferred to the soil, an extra-cuticular transpiration occurs, due to the humidity in the air in vivo is lower than in the in vitro environment. On the other hand, their stomata are not sufficiently operative, they remain open during the transplant to the -soil, provoking an important hydric stress in the first hours of the plants in the conversion phase 
(Hazarika, 2003). That is why the seedlings show a rapid wilting when transferred to greenhouse conditions, so it is necessary to maintain a high relative humidity in the new environment, to avoid damage to the mechanisms that maintain the volume of water in the plant (Fila et al., 2006).

When somatic embryo plants are transferred to ex vitro conditions, these could easily be affected by abrupt changes in environmental conditions and therefore require a period of adaptation. The objective of the acclimatization phase is to obtain a high survival of the plants, for which the environment (light, relative humidity, temperature, etc.) must be manipulated so that at the beginning of the phase the conditions where the plants are grown simulate in vitro conditions (Rodríguez et al., 2000).

Sorghum is a C-4 metabolism plant so it tolerates extreme temperatures. Temperatures below $10^{\circ} \mathrm{C}$ and above $42^{\circ} \mathrm{C}$ will stop growth, while the optimum values oscillate between $32^{\circ} \mathrm{C}$ and $34^{\circ} \mathrm{C}$ (Gutjahr et al., 2013). In the conditions of temperature and humidity in which the experiment was developed, the botanical seeds initiated the germination between five and ten days. In this regard, Zhao et al. (2018) pointed out that sorghum seeds have a small amount of starch, protein and fat content, which are rapidly depleted long before there is enough leaf development for photosynthesis. For this reason, plants from botanical seed grew slowly in the first three weeks of planting, from then on the growth rate increased rapidly.

The plants used in the present work had an in vitro height $\geq 3 \mathrm{~cm}$ with a high percentage of survival. However, Sadia et al. (2010) obtained in vitro plants transferred to greenhouse via direct organogenesis of higher height (4-5 cm) for their acclimatization ex vitro and reached $80 \%$ survival.

When evaluating the qualitative morphological characters in the plants derived from somatic embryos no albino nor variegated plants were found, and this corresponded with the plants propagated by botanical seed. In this regard, Pola et al. (2007) found correspondence in the morphological and physiological characters of sorghum plants from populations obtained in vitro and by botanical seed, at the end of the conversion phase.

Plants regenerated from somatic sorghum embryos were able to adapt and grow normally. The conversion of somatic embryos reached a 100\% survival in a substrate composed of earthworm humus (80\%) plus Zeolite (20\%) (T2), and the plantlets showed phenotypic stability evaluated through the ex vitro morphological characterization.

The results can be applied to the in vitro propagation of elite plants selected as a product of conventional breeding programs and obtained through the use of different biotechnological methods.

\section{CONCLUSIONS}

Sorghum is considered as recalcitrant to in vitro cultivation and genetic transformation, so our results contribute to modern agriculture by enhancing up to $100 \%$ the survival of regenerated in vitro plants via direct organogenesis from mature seeds, with the earthworm substrate humus $(80 \%)$ and zeolite $(20 \%)$. The phenotypic stability of regenerated plants was evidenced through morphological and agronomic characterization in green house conditions during two generations. The population of plants obtained from somatic embryos showed significantly higher values in terms of plant height, stem diameter, limb width and fresh and dry panicle mass.

The methodology developed for regeneration of plants via somatic embryogenesis is suitable for in vitro propagation of elite plants selected from conventional sorghum breeding programs obtained through several biotechnological techniques. Theoretical-practical elements on the process of somatic embryogenesis and the phenotypic stability of the plants to progeny R1 of great importance for the national and international scientific community are provided.

\section{Authors' contributions}

Silvio de J. Martínez Medina: Experiment conduction and data analysis Raúl Barbón Rodríguez: Experiment conduction and literature review; Rafael Gómez-Kosky: Experiment conduction and paper writing; Novisel Veitía Rodríguez: Data analysis; María Esther González Vega: Experiment conduction and paper writing; Orlando Saucedo Castillo: Experiment design; Eduardo Fidel Héctor Ardisana: Paper writing; Sandra Pérez Álvarez: Paper writing.

\section{REFERENCES}

Al-Saied, H., F. Al-Beskii and I. Askoul. 2014. Standardization of tissue culture protocols for callus induction and plant regeneration from mature embryo of sorghum [Sorghum bicolor (L.) Moench]. Int. J. ChemTech. Res. 6(5): 2710-2718.

Amali, P., S. Kingsley and S. Ignacimuthu. 2014. Enhanced plant regeneration involving somatic embryogenesis from shoot tip explants of Sorghum bicolor (L. Moench). Asian J. Plant Sci. Res. 4: 26-34.

Assem, S. K., M. M. Zamzam and B. A. Hussein. 2014. Evaluation of somatic embryogenesis and regeneration in tissue culture of ten sorghum (Sorghum bicolor L.) genotypes. Afr. J. Biotechnol. 13(36): 3673-3681.

Barbon, R., H. Nguyen, A. Capote, M. de Feria, A. Pérez, L. Rivero, M. 
Leiva and O. Hurtado. 2014. Efecto de mezclas de sustratos en la fase de conversión de plantas de Coffea arabica L. cv. 'Caturra rojo' obtenidas por embriogénesis somática. Biotecnol. Veg. 14(4): 205-213.

Baskaran, P., B. Raja-Rajeswari and N. Jayabalan. 2005. A simple approach to improve plant regeneration from callus culture of Sorghum bicolor (L.) Moench for crop improvement. J. Agric. Technol. 1(1): 179-192.

Bonilla, M. M., M. S. A. Sánchez and J. Pachón. 2015. Evaluación de sustratos orgánicos para la aclimatación y endurecimiento de vitro plantas de yuca (Manihot esculenta Crantz). Rev. Investig. Agrar. Ambient. 6(2): 31-36.

Davies, P. J. (Ed.), 2010. The plant hormones: Their nature, occurrence, and functions. In: Plant Hormones, Springer, Dordrecht.

Díaz, L. P., L. F. Medina, J. Latife, P. A. Digonzelli and S. B. Sosa. 2004. Aclimatación de plantas micropropagadas de caña de azúcar utilizando el humus de lombriz. RIA. 33(2): 115-128.

Dineen, L. C. and B. C. Blakesley. 1973. Algorithm AS 62: Generator for the sampling distribution of the Mann-Whitney $U$ statistic. Appl. Stat. 22: 269-273.

FAO. 2016. Sorgo Producción Mundial. Producción Mundial de Sorgo. 2016-2017. Available from: https://www.produccionmundialsorgo. com/previous-year.asp. [Last accessed on 2016 Sep 21].

Fila, G., F. W. Badeck, S. Meyer, Z. Zerovic and J. Ghashghaie. 2006. Relationships between leaf conductance to $\mathrm{CO} 2$ diffusion and photosynthesis in micropropagated grapevine plants, before and after ex vitro acclimatization. J. Exp. Bot. 57(11): 2687-2695.

González, M. 2014. Maduración y germinación de embriones somáticos de lináloe in y ex vitro. Tesis de Maestría, Instituto de Enseñanza e Investigaciones en Ciencias Agrícolas, Mayabeque, Cuba. Available from: https://www.text-mx.123dok. com/document/dzxvwloy-maduracion-y-germinacion-deembriones-somaticos-de-linaloe-in-vito-y-ex-vito.html.

Gurel, S., E. Gurel, R. Kaur, J. Wong, L, Meng, H. Tan and P. Lemaux. 2009. Efficient, reproducible agrobacterium-mediated transformation of sorghum using heat treatment of immature embryos. Plant Cell Rep. 28: 429-444.

Gutjahr, S., A. Clément-Vidal, A. Soutiras, N. Sonderegger, S. Braconnier, M. Dingkuhn and L. Delphine. 2013. Grain, sugar and biomass accumulation in photoperiod-sensitive sorghums. II. Biochemical processes at internode level and interaction with phenology. Funct. Plant Biol. 40: 355-368.

Hassan, L. B., S. Inuwa, M. Katung and S. Bugaje. 2014. Optimum protocol for shoot formation in karandafi red sorghum (Sorghum bicolor (L.) Moench) through somatic embryogenesis using mature embryo. Am. J. Plant Sci. 5: 671-675.

Hazarika, B. N. 2003. Acclimatization of tissue-cultured plants. Curr. Sci. 85(12): 1704-1712.

Henny, R. J., D. J. Norman and J. Chen. 2004. Progress in ornamental aroid breeding research. Ann. Mo. Bot. Gard. 91(3): 464-472.

Hurtado, O., M. Freire-Seijo, M. Leiva-Mora and Y. García-Ramíre. 2012. Efecto del tipo de sustrato en la aclimatización de plantas cultivadas in vitro de $B$. vulgaris var. Vulgaris. Biotecnol. Veg. 12(2): 85-91.
IBM. SPSS Statistics for Windows, Version 21.0. 2013, IBM Corporation, Armonk, New York, USA.

Ignacimuthu, S. and A. Premkumar. 2014. Development of transgenic Sorghum bicolor (L.) Moench resistant to the Chilo partellus (Swinhoe) through agrobacterium-mediated transformation. Mol. Biol. Genet. Eng. 2: 1-8.

Instituto de Investigaciones de Granos (IIG). 2016. Informe Anual Sobre la Producción de Granos, Ministerio de la Agricultura, Cuba.

Kruskal, W. H. and W. A. Wallis. 1952. Use of ranks in one-criterion variance analysis. J. Am. Stat. Assoc. 47(260): 583-621.

MINAG. 2005. Registro de Cultivares Comerciales. Dirección de Semillas. Ministerio de la Agricultura, Cuba.

Pérez, A., O. Saucedo, J. Iglesias, H. Wencomo, F. Reyes, G. Oquendo and I. Millán. 2010. Caracterización y potencialidades del grano de sorgo (Sorghum bicolor (L.) Moench). Pastos Forrajes. 33(1): 1-17.

Pola, S., N. Saradamani and T. Ramana. 2007. Enhanced shoot regeneration in tissue culture studies of Sorghum bicolor. J. Agric. Technol. 3: 275-286.

Pola-Sudhakar, R. and N. M. Sarada. 2006. Somatic embryogenesis and plantlet regeneration in Sorghum bicolor (L.) Moench, from leaf segments. J. Cell Mol. Biol. 5(2): 99-107.

Polumahanthi, S., S. Dora and N. S. Mani. 2014. Efficient callus induction protocol for Sorghum bicolor. Asian J. Plant Sci. Res. 4(3): 14-21.

Rodríguez, R., M. Escalona, C. Rodríguez and J. L. Gonzáles. 2000. Aclimatización de plántulas de caña de azúcar (Saccharum sp. Híbrido) provenientes de sistemas de inmersión temporal. Cultiv. Trop. 2(13): 51-56.

Sadia, B., P. Josekutty, S. Potlakayala, P. Patel, S. Goldman and S. Rudrabhatla. 2010. An efficient protocol for culturing meristems of sorghum hybrids. Int. J. Exp. Bot. Phyton. 79: 177-181.

Salvador, Z. H., M. A. Hernández, J. E. M. Ayala, R. S. Guzmán, C. A. Borja, M. T. Alvarado and R. V. Calderón. 2007. Guía Técnica del Sorgo (Sorghum bicolor L. Moench). $1^{\text {st }}$ ed. La Libertad, El Salvador. Available from: http://www.centa.gob.sv.

Sangeetha, C. and P. Baskar. 2016. Zeolite and its potential uses in agriculture: A critical review. Agric. Rev. 37(2): 101-108.

Shapiro, S. S. and Wilk, M. B. 1965. An analysis of variance test for normality (complete samples). Biometrika. 52(3-4): 591-611.

Shihe, F., S. Grossnickle, M. Rise, S. Attree and R. Folk. 2006. Method of ex vitro Sowing, Germination, Growth and Conversion of Plant Somatic Embryos or Germinants and Nutrient Medium used Therefor. United Stated Patent Application Publication. Publication No. US 2006/0088935 A1.

Zhao, M., H. Zhang, H. Yan, L. Qiu and C. C. Baskin. 2018. Mobilization and role of starch, protein, and fat reserves during seed germination of six wild grassland species. Front. Plant Sci. 9: 1-11.

Zhong, H., W. Wang and M. Sticklen. 1998. In vitro morphogenesis of Sorghum bicolor (L.) Moench: Efficient plant regeneration from shoot apices. J. Plant Physiol. 153(5-6): 719-726. 